\title{
Local Wisdom Of Subak As A Model Of Character Building For Social Studies Learning In Schools
}

\author{
I Putu Sriatha ${ }^{1}$, I Nyoman Jampel ${ }^{2}$, I Wayan Widiana ${ }^{3}$, I Gede Astra Wesnawa ${ }^{4}$ \\ Department of Geography Education ${ }^{14}$, \\ Department of Education Technology ${ }^{2}$, Department of Primary School Education Teacher ${ }^{3}$ \\ Universitas Pendidikan Ganesha \\ Singaraja, Indonesia \\ putusriartha@gmail.com¹ ${ }^{1}$ nyoman.jampel@gmail.com ${ }^{2}$,wayan_widiana@yahoo.co.id ${ }^{3}$,gede_astrawesnawa@yahoo.co.id ${ }^{4}$
}

\begin{abstract}
This study aimed to trace back any character values contained in local wisdom of the Balinese traditional irrigation system called Subak and to construct it as a model of character building for social studies learning in schools. To obtain the objective, this study made use a meta-analysis approach. The primary sources of data were all research findings which have been published in either relevant national or international journals along recent seven years (2011-2017). The data and findings of the study were analyzed and formulated by using a descriptive-interpretative technique. The finding of the study was 17 character values in local wisdom of Subak which was related to the national character formation. The notion of Subak based character building in social studies learning was applied into a model of indoor-outdoor study. The notion needs testing to measure the effectivity of its implementation and its constraints through further researches.
\end{abstract}

Keywords—subak, character education, social studies learning

\section{INTRODUCTION}

Education has tremendously strategic roles in forming national character. Unfortunately, the education practice in schools that occurs nowadays have not optimally accommodated and integrated the development of character values. Evaluates that currently ongoing education building have not given significant outcomes in national character formation based on normative values of Indonesian nationality [1]. Competence which is developed in current education system and practice have not been balanced, still loaded with knowledge transfer, focused on text books and separated from student's potential local environment [2].

Education system and practice above are contradictive with government policy which emphasizes the developed curriculum in schools must be associated with society potentials and their local environment. The appeared effect of contradiction is apprehensive which can be seen from spreading deviant behavior of students and young generation, such as driveway, student brawl, free sex, drug abuse, alcohol, abortion and many others. Furthermore, they show some symptoms of leaving local culture to accommodate the western one. This appears in arts, fashion, favorite, appetite, entertainment, language, life style, children-parent interaction, student-teacher interaction, danger of secularism, pragmatism and hedonism.

The complexity of moral dieses and character degradation which are conducted by society and Indonesian nation implicate on the necessity of education revitalization by setting the schools not only as a teaching-learning center loaded with academic scores as it always occurs, but also setting the schools as culture appreciation and development by gaining advantages on local Indonesian various cultures that contains nation character. Along this context, education character which is grounded on local wisdom is considered prominent to be developed in education system and practices in schools.

Balinese society has various uniqueness on local culture, one of which is called subak system. Subak system refers to a traditional communal farmer organization that manages and controls irrigation water and crops planting mechanism based on philosophy of Tri Hita Karana (THK). Subak system has been determined by UNESCO as the world cultural heritage on its assessment that subak was born from culture of Balinese society based on the concept of Tri Hita Karana (THK ) including local wisdom which has proved to reflect authentic outstanding universal values, one of them is a strong value as an adhesive between social and ecological conservationists [3]. The findings of scientific study of both the international and national experts show that subak has various universal value of local wisdom and can be gained advantages as a model of harmonic society life. Some of the uniqueness can be identified that (1) Subak is the most effective and sophisticated farmer organization in the world in controlling irrigation water [4] , [5], ( 2) Subak is remarked as socioreligious pattern based on Tri Hita Karana (THK) that contains universal values and plays roles in forming development of sustainable agriculture and principles of a good governance [6] , [7] , [8] , [9], and (3) Subak has plural roles as an asset of local culture conservation, an actor of social and economic life empowerment, an actor of environment conservationists organization, especially landscape and water and an actor of organization of political aspiration [10].

Though the findings of the study express various valuable local wisdom of subak mentioned above, in fact, it has not 
been applied yet as a device of forming students' character through education practice, especially in practical teachinglearning process of social studies in junior high schools. This condition is supported by literature and empirical study showing that research and practice that were integrated local wisdom of subak into for social studies learning was limited in a mount. The developing the learning through local wisdombased social studies learning is considered important due to the scope of study and laboratory of the lesson is society and their interaction with surrounding environment. Furthermore, the importance of developing social studies learning based on local wisdom of subak is grounded by empirical condition that the learning of the lesson in schools underwent many kinds of problems and weaknesses. The weakness of social studies learning can be seen from two side. First, from content side of view, conceptual and empirical resources that were used as references of the learning the lesson was still curriculum centered and ignored the local wisdom as its sub contents. Second, from learning side of view, the lesson was sourced from the text books, ignoring the benefit of social life and students' environment as one learning sources, especially the values of local wisdom conducted by local society so it then can bear unpowerful instrumental output. This text book could not provide any opportunity to the students to empower themselves, only focused more on the formal requirements than the real needs of students that it is of course boring and tiring. [11]

Based on the description above, it is important to conduct a research about local wisdom of subak as a model of education character in social studies learning in schools. Related to that, the writing of this paper is to (1) trace back character values that contains in local wisdom of subak and (2) propose a model of education character based on local wisdom of subak in social studies learning in junior high school.

\section{RESEARCH METHOD}

This study made use a meta-analysis approach. The main primary source of data was research finding which have been published in either national or international journals along recent seven years (2011-2017). The selection of journals was based on the consideration of (1) journals which have relevant substance to the topic and problem of the study (2) accredited national journals and international journals that have official recognition from international institutions, preferably reputable journals (indexed in Scopus or Web of Science and has an impact factor). Based on these considerations, ten journals were defined : (1) Sustainable Agricultural Development in Bali: Is the Subak an Obstacle, an Agent or Subject? [12]. (2) The Functional Role of Balinese Water Temples: A Response to Critics [13]. (3) Cross culture Learning: Utilizing subak as a Model of Ecopedagogy [14]. (4) Exploring Community Capital of the Balinese Subak Cultural Heritage: A Content Analysis of Participatory Maps[15]. (5) The Effect of Regional Development on the Sustainability of Local Irrigation System (A Case of Subak System in Badung Regency, Bali Province) [16]. (6) Spatial Zonation Model of Local Irrigation System (A Case of Subak
System in Bali) [17]. (7) Effectiveness of the Implementation of Local Government Policy in Controlling the Conversion of Subak Rice Field Land: Case Study in Badung Regency, Bali [18]. (8) Rituals Aspek in Subak Irrigation System as World Cultural Heretage [19]. (9) Balinese Local Wisdom and Their Implication in Science Education at School [2]. (10) Changing Realities-Perspectives on Balinese Rice Cultivation [20].

The study was started by considering the problems and objective of the study and traced back the newest and the most relevant research findings. The next steps were to review, analyze, and choose the content of research findings. The further action was to conduct an interpretation, signify and formulate the findings. Data analysis and research findings formulation was conducted by using descriptive technique.

\section{CHARACTER VALUES IN LOCAL WISDOM OF SUBAK}

Fundamentally, local wisdom is a capital of culture belonged by local society which inherited traditionally and contains truth values, wisdom, cleverness and kindness applied as philosophical base to behave well and right in forming harmonic life [12], [1]. Local genus has strategic roles in forming national character, that is character of Indonesian personality which is appropriate with values of Pancasila and norms of UUD 1945, diversity with the principle of Bhineka Tunggal Ika, and the commitment towards NKRI [13]. Therefore, local wisdom has significance and relevance of character building.

Studies of character values and the experts show the similarity of notion about items of characters which are considered ideal even though there are some differences. For instance, some items of character considered ideal consisted of 18 items with character values are: (1) religious, (2) honest, (3) tolerant, (4) discipline (5) hard work, (6) creative, (7) independent, (8) democratic, (9) curious, (10) national spirit, (11) love for the home land, (12) appreciate achievements, (13) be friendly/ communicative (14) love piece, (15) keen on reading (16) environmental care (17) social care, and (18) responsible. Those items of character values are considered base in trace back the character values in local wisdom of subak [14].

Fundamentally, subak is a group of society or institution that control the irrigation water and manage mechanism of crops on landscape of rice field and source of water has temples and autonomic on basis of philosophy of Tri Hita Karana (THK). The meaning of THK is the three ways to proceed life happiness, that are (1) parhyangan (creating harmony between human and God) (2) pawongan (harmony between human and other human), and (3) pelemahan (harmony between human and natural environment). Therefore, the application of philosophy of THK in all activities, subak is acknowledged as the core and the buffer of Balinese culture and excellence as a model of harmonic society that support sustainable life. That is the reason subak is declared by UNESCO as the world cultural heritage that must be protected [3], [16], [17], [18]. The character values 
contained in Subak local wisdom can be extracted from the implementation of components of $T H K$ philosophy which is pahrayangan, pawongan, and palemahan.

The applying the component of parhyangan basically is the shape of culture represented in strong faith and belief of the members (farmers) of subak that water and rice field is creation of God therefore it must be respected and conserved well. On behalf of the, the members of subak builds holy place called subak temple and conduct ceremony and religious ritual. Temples and ritual activities in subak are conducted occasionally both individual level and Subak level. The ritual ceremony at the farmer level is carried out in each farmer's field. Each farmer paddy block has a sanctuary called sanggah catu which placed near the gate that drains the water into the paddy field (pengalapan). Windia, et al (19] recorded sixteen types of ritual ceremony that conducted at the farmer level, from ngendagin/memungkah (ceremony for the beginning of the land cultivation), pengwiwit/ngurit (ceremony held after sowing the seeds), to mantenin, the post-harvest ceremony conducted in the rice storage area (lumbung padi). Meanwhile, the ceremony at the subak level and between subak are mendak toya (ceremony to pick up the water to the water sources (dam, lake, spring)), and nangkluk merana (ceremony for pest control and prevention of plant diseases).

Subak temple has functional hierarchy, ranging from farmer level to the highest temple namely Pura Ulun Danu. Langsing and Therese A. De vet [20] reveal the hierarchy of the subak temple from the lowest to the highest that is Pura Bedugul, Pura Ulun Carik, Pura Ulun Siwi, and two highest temples namely Pura Ulun Danu Beratan, and Pura Ulun Danu Batur. Basically, all the temples and those ritual of Subak symbolize the expression of belief on God blessing that has been spread in the form of water, fertile land, and fruitful harvesting.

Besides that, there are also temples built on empty space of every water damp (empelan) and water division (tembuku) show meaning as control mechanism of God, so farmers are afraid to cheat the water flow because they believe in punishment from God (karmaphala law) and this religious notion can prevent internal conflict in subak. Langsing and Therese A. De Vet [20] through their research have proved that the subak temple network allows the farmers to apply the irrigation schedule, planting season, and subak disputes settlement. This network also can create an optimal balance between water distribution and plant pest control through synchronization or coordination in the fallow period. Synchronization of irrigation and ceremonies means fewer pests. Their discovery shows that the temples and rituals of subak also have a social fuction as a unifier of group integrity and ecological function as a controller of plant pests and diseases. Component of pawongan is implemented in the form of collective life through social interaction among subak members that are regulated in communal law called awig-awig and based on principles of paras paros sarpanaya, and sagilik saguluk selunglung sebayantaka.
Awig-awig or Balinese traditional law controls right, duty, and sanction that is legitimated in front of the God. Therefore, awig-awig is very much respected by all members of subak so the peace and social harmony can be achieved. Principle of parasparos sarpanaya means that we are part of others and others belong to us (meaning the same with helping one another, believe one another, and respect one another). Principle of sagilik saguluk selunglung sebayantaka means that good-bad, live-die are taken together (same boat and carried the same weight, cooperative, and working together). Subak has flexible organization structure that every decision is drawn and stated together in subak meeting periodically.

Cooperation becomes the main principle adopted in subak system, especially in operation and maintenance of the irrigation system. Joint operation and maintenance of the irrigation system means less work for the individual and joint water management means group pressure on free-riders. Subak as Balinese irrigation system which guarantees cooperative and institutional framework for farming households to maintain the collectively owns irrigation infrastructure. Besides that, the subak offers the adaptable structure which is necessary to fit the different needs of its members [20]. The subak is merely a supportive framework to allow farmers to manage rice production as smoothly as possible, assuring continuous access to irrigation water, minimizing free-riding through joint responsibilities in management and operation, and guaranteeing the protection of the crop by organizing ceremonies and setting a cultivation schedule [18].

The applying the component of palemahan basically is associated with controlling the use of water, rice field and crops sustainably. Technical water irrigation allocation is based on principle of fairness with tektek system. This system is about the right measure to water which is allocated to every member of subak generally based on size of rice field cultivated.by the farmers. The wider the rice field the more right to water the farmer get. This is implicated to the bigger obligation that must be taken by the member of subak, like the obligation of ayahan (energy), sarin tahun (annual fare), and pepesuan (other fine). In distributing and allocating the irrigation water, subak applies a system of pelampias, that is by giving more water to those whose rice field is in downstream, a system of water loan agreement, and water or crops rotation system which are controlled together by the farmers. This can be signified as form of being togetherness and cooperation.

Water distribution in division construction (tembuku) is made by using a system of numbak, that reflects fairness and ease in keeping it. The most apparent production technique in subak is the agreement of pattern and schedule with a system called kertamasa (planting all at once) therefore cycles of insects can be terminated or prevented. Controlling insects and dieses is conducted by spiritual approach which is called nangluk merana (expelling danger). System of kertamasa and nangkluk merana has function of environment conservation.

Based on the THK philosophy has proved that subak is considered as the unique irrigation system, most effective 
local irrigation management in the world, as stabilizer of social and cultural life and democracy model, as regulator of ecosystem, as enabler of food security, and as application of good governance [12], [16], [17].

The analysis of character value through application of THK of subak mentioned above, can be summarized in the following table 1 .

TABLE 1. CHARACTER VALUES IN LOCAL WISDOM OF SUBAK

\begin{tabular}{|c|c|c|}
\hline THK & Application of Local Wisdom & $\begin{array}{c}\text { Character } \\
\text { Values }\end{array}$ \\
\hline \multirow[t]{5}{*}{1} & $\begin{array}{l}\text { 1. Water and land are creation of God, } \\
\text { human is obliged to keep and respect } \\
\text { them }\end{array}$ & Religious \\
\hline & $\begin{array}{l}\text { 2. Subak Temples and ritual are belief } \\
\text { expressions of gratitude on God } \\
\text { creation. }\end{array}$ & Religious \\
\hline & $\begin{array}{l}\text { 3. Temples function as control } \\
\text { mechanism of God on behalf of } \\
\text { honesty due to the belief of } \\
\text { karmaphala law }\end{array}$ & Honesty \\
\hline & $\begin{array}{l}\text { 4. Every empty land in every damp and } \\
\text { water division construction used to } \\
\text { build temples }\end{array}$ & $\begin{array}{l}\text { Togetherness } \\
\text { and } \\
\text { peacefulness } \\
\text { (love peace) }\end{array}$ \\
\hline & $\begin{array}{l}\text { 5. Pattern and crop rotation schedule are } \\
\text { agreed at the moment of ritual } \\
\text { ceremony in subak temples witnessed } \\
\text { by God }\end{array}$ & $\begin{array}{l}\text { Integrity } \\
\text { Unifier and } \\
\text { care of } \\
\text { environment } \\
\text { conservation }\end{array}$ \\
\hline \multirow[t]{3}{*}{2} & $\begin{array}{l}\text { 1. The existence of awig-awigor subak } \\
\text { law is applied directly and openly } \\
\text { (rule in use) }\end{array}$ & $\begin{array}{l}\text { Law-abiding, } \\
\text { openness, } \\
\text { discipline }\end{array}$ \\
\hline & $\begin{array}{l}\text { 2. Principles of paras paros sarpanaya } \\
\text { sagilik saguluk selunglung } \\
\text { sebayantaka. }\end{array}$ & $\begin{array}{l}\text { Tolerance } \\
\text { (mutual respect } \\
\text { and trust), } \\
\text { social care } \\
\text { (mutual help, } \\
\text { mutual } \\
\text { cooperation) }\end{array}$ \\
\hline & $\begin{array}{l}\text { 3. Organization structure based on subak } \\
\text { environment is autonomous so the } \\
\text { decision and agreement are taken in } \\
\text { subak meeting }\end{array}$ & $\begin{array}{l}\text { Flexible, } \\
\text { adaptive, } \\
\text { democratic, } \\
\text { and } \\
\text { independent }\end{array}$ \\
\hline
\end{tabular}

\begin{tabular}{|c|c|c|}
\hline THK & Application of Local Wisdom & $\begin{array}{l}\text { Character } \\
\text { Values }\end{array}$ \\
\hline & $\begin{array}{l}\text { 4. Obligations of member are considered } \\
\text { on the base of equal right to water and } \\
\text { position of members as ayahan, sarin } \\
\text { tahun, and pepesuan. }\end{array}$ & Responsibility \\
\hline \multirow[t]{6}{*}{2} & $\begin{array}{l}\text { 1. The allocation of water irrigation is } \\
\text { referred to a system called tektek. }\end{array}$ & Justice \\
\hline & $\begin{array}{l}\text { 2. Water division construction (tembuku) } \\
\text { is made by a numbak system. }\end{array}$ & Justice \\
\hline & $\begin{array}{l}\text { 3. There is a system called pelampias } \\
\text { that is by giving more water to those } \\
\text { whose rice field is in downstream }\end{array}$ & $\begin{array}{l}\text { togetherness, } \\
\text { mutual help, }\end{array}$ \\
\hline & $\begin{array}{l}\text { 4. Applying crop planting pattern or } \\
\text { mechanism called kertamasa. }\end{array}$ & $\begin{array}{l}\text { Environment } \\
\text { conservation }\end{array}$ \\
\hline & $\begin{array}{l}\text { 5. Applying the system of water loan } \\
\text { agreement and rotation system }\end{array}$ & $\begin{array}{l}\text { Mutual help to } \\
\text { cover water } \\
\text { scarcity } \\
\text { (environment } \\
\text { conservation) } \\
\text { cooperative. }\end{array}$ \\
\hline & $\begin{array}{l}\text { 6. Applying water flow controlling } \\
\text { system (one-inlet/pengalapan) and } \\
\text { removal system (one- } \\
\text { outlet/pengutangan) of water on each } \\
\text { block of farmer's land. }\end{array}$ & $\begin{array}{l}\text { Mutual help to } \\
\text { cover water } \\
\text { scarcity } \\
\text { (environment } \\
\text { conservation) }\end{array}$ \\
\hline
\end{tabular}

Resource: Results of Meta-Analysis [Sriartha, 2017].

Based on the table 1 above, seventeen dominant character values contained in local wisdom of subak were recorded, including: religious, honest, togetherness (cooperative), love peace, unification environment care, social care, law-abiding, discipline, openness, flexible, adaptive, democratic, independent, justice, and responsible. Those character values are relevant to be developed as a model of character building in social studies learning in schools to Indonesian nation characters 


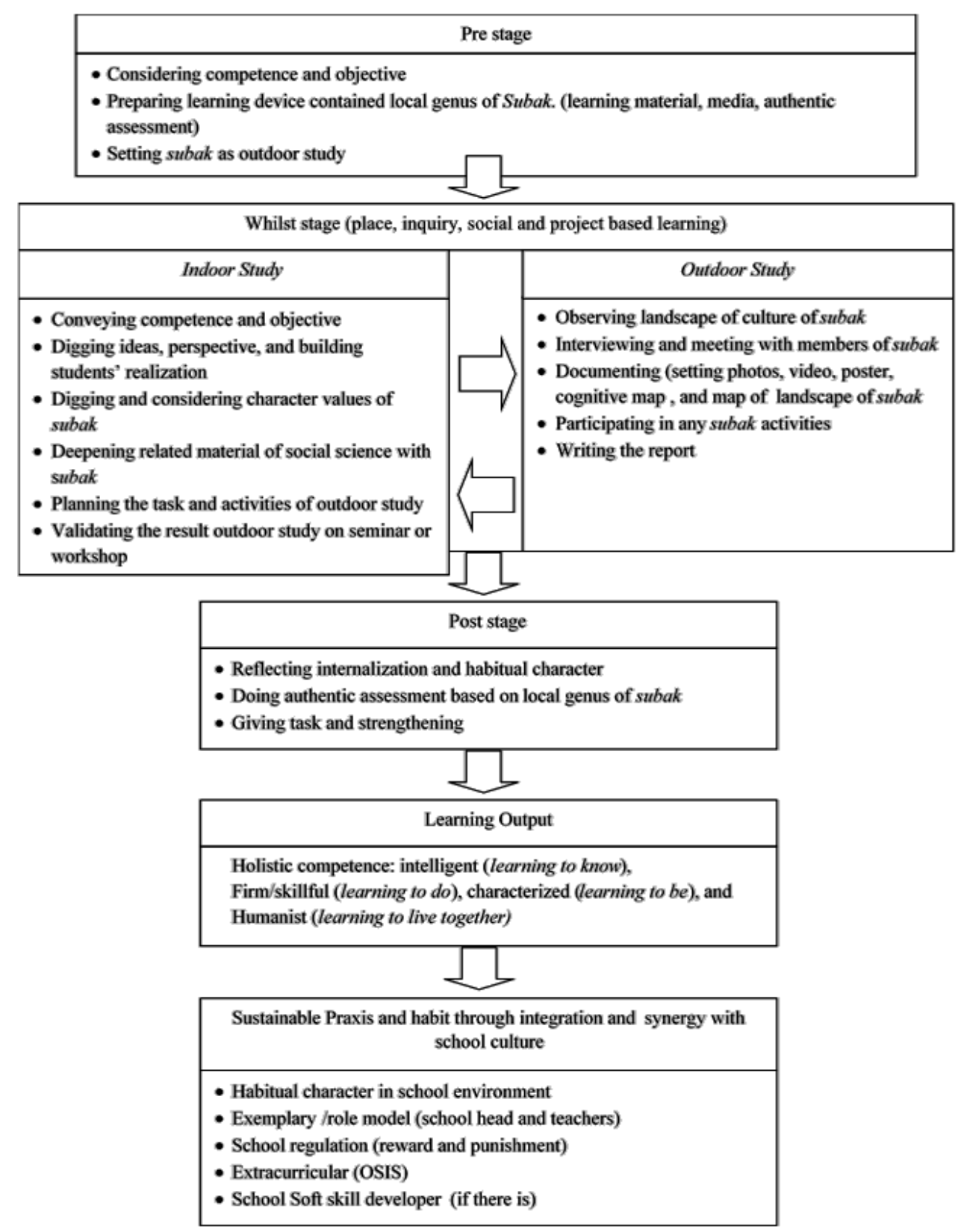

Fig. 1. Model of character building in social studies learning (conceptual notion)

\section{A MODEL OF CHARACTER BUILDING IN SOCIAL STUDIES LEARNING IN JUNIOR HIGH SCHOOLS}

Character values which are identified in local wisdom of subak above, are basically nation character values. Those values are relevant with competence that are considered in curriculum of social studies for junior high schools (IPS SMP/MTs) 2013. The model of integrating character building into social studies learning which has been applied till now is still dominated by class based, less direct oriented to society area. This model is clearly contradictive to material area of social studies, that is society or community. The researcher who involved society as learning laboratory in social studies learning was still limited. Similar research among others conducted was in the form of an integrative echo- pedagogic learning model within community service and research based learning $(C R L)$ by involving teacher candidate students, to recontextualize the curriculum of basic education level by establishing the critical and creative mind, enjoyable and move forward to basic learning competence achievement: intelligent (learning to know), firm (learning to do), honest (learning to be), and care (learning to live together) [14]. Other similar research which was also was a cross culture point of view by using subak as model of ethnopedagogy. The study found that cross culture learning by implementing ideas of subak as model of ethnopedagogy was effective to be applied in establishing student's realization as young 
generation in utilizing last culture heritage to build their future, so this model is considered significant for sustainable education [15]. Local wisdom of community (including subak) in social studies learning can be developed and integrated in components of curriculum, starting from objective of learning, material, process and assessment.

Flashing back from the findings of meta-analysis towards character values contained in local wisdom of subak, the research about a model social studies learning, competence and material scope in curriculum of social studies for level of junior high schools (SMP/MTs) 2013, the model of character building in social studies learning is called integrative indooroutdoor study. The application of this learning model is planned into three stages, those are pre-stage, whilst stage and post stage. Those three stages of learning activities can be visualized in the following figure 1.

The notion of above model has strength as it can reduce barrier between learning inside the class room and real life in society, between modern science (identified with western science) and local knowledge, and can develop students' competence holistically, that is student's basic competence considered intelligent (learning to know), firm/skillful (learning to do), characterized (learning to be), and humanist (learning to live together). In its implementation needless to say, there will be obstacles within the process, some of them can be the problem in controlling the time at the moment of outdoor study, problem in utilizing subak as place of outdoor study especially the schools that are in cities, far from the location of subak, and any other problems. Therefore, to recognize the effectivity of implementation and problems that appear, it is considered essential to validate through further research.

\section{CONCLUSION}

Developing local wisdom of subak as a model of character building in social studies learning in junior high schools has reciprocal benefit. On one side, it can increase social studies learning more meaningful, contextualized with real life, strengthen education as a process of culture to build nation character and establish students' competence holistically. On the other side, as the same time, this model can sustain the local wisdom of subak which is internationally acknowledged as protected culture heritage of Balinese ancestor. The finding of the study by using meta-analysis found 17 character values contained in local wisdom of subak that can be developed as a device character building. To develop those character values, it has been constructed a model of character building of local subak in social studies learning which is called indoor-outdoor study. The model needs validated and tested through further relevant research to recognize its effectivity and the problems of the implementation.

\section{ACKNOWLEDGMENT}

The researcher would like to be grateful to Prof. Dr. Wayan Windia, M.S., the head of center study of Subak, Udayana University who has helped to give a lot of references to support the study. Feeling thankful is also addressed to the head of LPPM Pendidikan Ganesha University for his support and motivation. Last but not least, saying thanks is also addressed to the committee of ICIRAD 2017 that have reviewed, given some valuable input and published this article in proceeding.

\section{REFERENCES}

[1] Atmadja, Nengah Bawa, Anantawikrama Tungga Atmadja, dan Tuty Maryati. Hindu Religion, Pancasila, and Foundation of Local Genus in Character Building (Agama Hindu, Pancasila dan Kearifan Lokal Fondasi Pendidikan Karakter), Denpasar: Pustaka Larasan, 2016.

[2] Suastra, I Wayan. Balinese Local Wisdom and Their Implication in Science Education at School. International Research Journal of Management, IT, and Social Sciences (IRJMIS), Vol 4, Issue 2, March 2017 (pages 42-50).

[3] Windia, Wayan and Wayan Alit Artha Wiguna. Subak as World Cultural Heritage (Subak Sebagai Warisan Budaya Dunia), Denpasar: Udayana University Press, 2013.

[4] Ostrom E. Crafting Institutions Self- Governing Irrigation Systems. San Francisco: Institut for Contemporary Studies, 1992.

[5] Ambler, John S. Farmer's Irrigation Dynamics: Framework and Institutional Priciples. In John S. Ambler (Ed), Irrigation in Indonesia: Institutional Dynamics. Jakarta: LP3ES, 1992.

[6] Ahimsa-Putra, H.S. Strategies to Transfer Subak Farming System to Non-Balinese Societies. In Sahid Susanto (Ed): A Study of the Subak As An Indigenous Cultural, Social. And Technological System To Establish A Culturally Based Integrated Water Resources Management, Volume I. Yogyakarta: Faculty of Agricultural Technology, Gadjah Mada University, 1999.

[7] Kasryno, Faisal., Effendi Pasandaran, dan Achmad M. Fagi. Local Wisdom of the Subak Syatem In Bali : A Model of Just and Sustainable Rural Development. Dalam Faisal Kasryno, Effendi Pasandaran, dan Achmad M. Fagi (Penyunting : Subak dan Kerta Masa, Kearifan Lokal Mendukung Pertanian Berkelanjutan. Jakarta: Yayasan Padi Indonesia (YAPADI), 2003.

[8] Baharsyah, Syarifudin. Local Wisdom As An Important Social Capital in Rice-Based Agriculture Development. Dalam Sumarno, Suparyono, Achmad M. Pagi, Made Oka Adnyana (Ed) : Rice Industry, Culture, and Environment, Book 1. Proceedings of the International Rice Conference, September 12-14, 2005, Tabanan Bali. Indonesian Agency for Agricultural Research and Development in Cooperation with International Rice Research Institute.

[9] Norken, N., W. Windia, J. Sushila, W. Geriya, M. Mudhina. Increasing effectivity of water resource management based on subak institution in Bali Province (Meningkatkan Efektivitas Pengelolaan Sumberdaya Air Berbasis Subak Di Provinsi Bali), Denpasar: BAPPEDA Provinsi Bali, 2007.

[10] Susanto S. Methodological Approach of Field Investigation on Developing Strategies of Culturally Based Water Resources Management. In Sahid Susanto (Ed) : A Study of the Subak As An Indigenous Cultural, Social. And Technological System To Establish A Culturally Based Integrated Water Resources Management, Volume III. Yogyakarta: Faculty of Agricultural Technology, Gadjah Mada University, 1999.

[11] Ismail, M., Sukardi dan Su’ud Surachman. Developing Sasak Society Local Genus Based Learning Model: towards Attitude and Democratic Behavior of SMP/MTs.students (Pengembangan Model Pembelajaran Berbasis Kearifan Lokal Masyarakat Sasak : Menuju Sikap dan Perilaku Demokratis Pada Siswa SMP/MTs), Jurnal Pendidikan dan Pengajaran, Jilid 142, Nomor 2, Juli 2009 (hal. 137).

[12] Macrae Graemes S. and I.W.A. ArthaWiguna. Sustainable Agricultural Development in Bali: Is the Subak an Obstacle, an Agent or Subject? Retrieved 16 October 2013 from Hum Ecol (2011) 39: 11-20, DOI 
10.1007/s10745-011-9386-y, Published online: 1March 2011, (C) Springer Science+Business Media, LLC 2011.

[13] Lansing, J. Stephen and Therese A. De Vet. The Functional Role of Balinese Water Temples: A Response to Critics. Retrieved 16 October 2013 from Hum Ecol (2012) 40: 453-467, DOI 10.1007/s10745-0129469-4, Published online: 1 May 2012, (C) Springer Science+Business Media, LLC 2012.

[14] Surata, Sang Putu Kaler. 2013. Cross culture Learning: Utilizing subak as a Model of Ecopedogogy (Pembelajaran Lintas Budaya: Pemanfaatan Subak sebagai Model Ekopedagogi ), Jurnal of Bali Study, Volume 03, Number: 02 (pages. 181-198)

[15] Surata, Sang Putu Kaler, Gusti Ayu Sri Rwa Jayantini, John Stephen Lansing. Exploring Community Capital of the Balinese Subak Cultural Heritage: A Content Analysis of Participatory Maps. International Journal of Technical Research and Applications, Volume 2, Special Issue 7 (pages 28-34), 2014.

[16] Sriartha, I Putu, Suratman, Sri Rum Giyarsih. The Effect of Regional Development on the Sustainability of Local Irrigation System (A Case of Subak System in Badung Regency, Bali Province). Forum Geografi, Indonesian Journal of Spatial and Regional Analysis, Volume 29, Issue 1, July 2015 (pages 31-40).

[17] Sriartha, I Putu and Sri Rum Giyarsih. Spatial Zonation Model of Local Irrigation System (A Case of Subak System in Bali). Indonesian Journal of Geography, Volume 47, No. 2, December 2015 (pages 142-150).

[18] Sriartha, I Putu dan Wayan Windia. Effectiveness of the Implementation of Local Government Policy in Controlling the Conversion of Subak Rice Field Land: Case Study in Badung Regency, Bali (Efektivitas Implementasi Kebijakan Pemerintah Daerah Dalam Pengendalian Alih Fungsi Lahan Sawah Subak Di Kabupaten Badung, Bali), Jurnal Kajian Bali (Journal of Bali Studies) Volume 05, Nomor 02, October 2015 (pages 327-346).

[19] Windia, Wayan, Sumiati, dan Gede Sedana, Ritual Aspect in Subak Irrigation System as World Cultural Heretige (Aspek Ritual dalam Sistem Irigasi Subak Sebagai Warisan Budaya Dunia), Jurnal Kajian Bali (Journal of Bali Studies) Volume 05, Nomor 01, April 2015 (pages 23-28).

[20] Lorenzen Rachel P. and Stephan Lorenzen. Changing Realities Perspectives on Balinese Rice Cultivation. Retrieved 10 November 2012 from Hum Ecol (2011) 39: 29-42, DOI 10.1007/s10745-010-9345-z, Published online: 17August 2010, @ Springer Science+Business Media, LLC 2010.

[21] Kriyantono, R. Teory of Public Relations Western Prospective and Lokal application of Research and practice (Teori Public Relations Perspektif Barat dan Lokal Aplikasi Penelitian dan Praktek ), Jakarta: Kencana Pernadamedia Group, 2014.

[22] Suyanto, Character Education Theory and Application ( Teori Pendidikan Karakter dan Aplikasi), Jakarta: Rineka Cipta, 2010.

[23] Zubaidi. Design of Character Building, Conception, and its Application in Education Institution ( Desain Pendidikan Karakter, Konsepsi dan Aplikasinya dalam Lembaga Pendidikan ), Jakarta: Kencana Predana Media Group, 2011 